мотиваційний, теоретико-когнітивний, практично-діяльнісний i діагностувальнорезультативний, кожен 3 яких побудовано відповідно до вимог освітнього процесу та художньо-творчого розвитку майбутнього вчителя образотворчого мистецтва. Визначено та обмотивовано мету, завдання, підходи і принципи, форми, методи і засоби навчання, а також критерії, показники та рівні сформованості основ художньої майстерності. Перспективи подальших наукових розвідок можуть бути пов'язані 3 дослідженням формування i становлення авторської школи, як показника найвищого рівня сформованості художньої майстерності.

\section{СПИСОК ДЖЕРЕЛ}

1. Басин Е. Я. Творческая личность художника. СПб. : Алетейя, 2015. 88 с.

2. Гераимчук И. М.Теория творческого процесса: Структура разума (интеллекта): монография / И. М. Гераимчук. - К. : Эдельвейс, 2012. $269 \mathrm{c}$.

\section{3. Гордаш А. Мистецько-освітня} концептуалізація категорії «Художня майстерність» / Естетика і етика педагогічної дії. 2019. Вип. 19. 276 с.

4. Энциклопедия профессионального образования: [ в 3-х т.] ; под ред. С. Я. Батышева М. : АПО, 1999. - Т. 3.440 с.

5. Словник української мови / [ред. П. Горецького]. - К. : Наукова думка,1970. 635 с.

\section{REFERENCES}

1. Basin, E. Ya. Tvorcheskaya lychnost' khudozhnyka. (2015). [The creative personality of the artist]. St. Petersburg.

2. Geraimchuk, I. M. Teoriya tvorcheskogo protsessa: Struktura razuma (intellekta). (2012).
[Theory of the creative process: The structure of mind (intelligence) ]. Kyiv.

3. Gordash, A. Mystets'ko-osvitnya kontseptualizatsiya katehoriyi «Khudozhnya maysternist'». (2019). [Artistic and educational conceptualization of the category «Artistic skill»]. Kyiv.

4. Éntsyklopedyya professyonal'noho obrazovanyya. (1999). [Encyclopedia of Vocational Education: [in 3 volumes]. Moskwa.

5. Slovnyk ukrayins'koyi movy.

(1970)

[Dictionary of Ukrainian]. Kyiv.

\section{ВІДОМОСТІ ПРО АВТОРА}

ЧЕРКАСОВ Володимир Федорович доктор педагогічних наук, професор, завідувач кафедри музичного мистецтва i хореографії Центральноукраїнського державного педагогічного університету імені Володимира Винниченка.

Наукові інтереси: становлення і розвиток музично-педагогічної освіти в країнах Європейського союзу, теорія і методика викладання музичних дисциплін.

\section{INFORMATION ABOUT THE AUTHOR}

CHERKASOV Volodimir Fedorovich Doctor of Pedagogical Sciences, Professor Department of Musical Art and Choreography of of Volodymyr Vynnychenko Central Ukrainian State Pedagogical University.

Circle of scientific interests: the formation and development of music-pedagogical education in the countries of the European Union, theory and methodology of teaching music disciplines.

Стаття надійшла до редакиії 25.01.2020 p

УДК 37.091.12.011.3

DOI: 10.36550/2415-7988-2020-1-186-69-73

ШАНДРУК Світлана Іванівна доктор педагогічних наук, професор, завідувач кафедри лінгводидактики та іноземних мов Центральноукраїнського державного педагогічного університету імені Володимира Винниченка ORCID: https://orcid.org/0000-0002-7472-4584 e-mail: sishandruk@ukr.net

\title{
THEORY AND PRACTICE OF HIGHER PROFESSIONAL EDUCATION IN UKRAINE
}

Statement and substantiation of the relevance of the problem. The process of association of Ukraine with European Union and integration into European and world educational spheres the features of which are related to the nature of global processes, and also with the specific terms of development of social, economic, political, cultural and educational life of our country, predetermines the demand of different problems decision. 
Dynamic processes of social and economic life, changes in the system of compulsory secondary education revealed contradictory tendencies in the sphere of professional preparation of teachers in Ukraine: deep professionalization of secondary school teachers' practice becomes more important; integration of knowledge from different spheres is noticed; importance of integrated skills and abilities for realization of professional pedagogical practice increases. These tendencies determine new demands for teachers because the task of preparation of secondary school graduates for world market integration, formation of comprehensive world idea, and adoption of cognitive and communicative methods of activity, ability to receive information from different sources is delegated to them.

Analysis of recent research and publications. Tendencies and challenges in professional activity of teachers can be qualified as global, national and regional. Inevitable transformation of consciousness as the result of globalization changes content and form of education. School plays an extraordinarily important role in this process. The role of education in globalization became a spotlight of international financial institutions which assist development of education and effective support of teachers. The use of technological achievement, in particular of distance education, creates the tendency of transporting of western conceptions into new regions and to the population, giving them knowledge, generated by culturally dominant groups, and helping them to join consumer society. Another tendency of introduction of world standards of professional education, practice and professional development in this context becomes urgent.

International educators contributed into theory and practice of teacher professional preparation in such aspects as: education reform (H. Beare, B. Caldwell, and others); professional education (C. Day, J. Sachs, and others); quality of professional preparation (M. Eraut, J. Leino, and others); skills, abilities and knowledge of teachers (A. Ismat, G. Shacklock, and others); professional development of teachers (C. Day, A. Ismat, G. Shacklock, and others).

Modern pedagogical processes require principle changes of the role of a teacher, his/her mutual relations with students, and his/her transformation into facilitator of students' cognitive activity. It also changes students into active subjects of cognition and transformation. Realization of tasks of professional preparation of teachers depends on the condition of pedagogical education that demands objective analysis of the accumulated international and national experience of pre-service and postgraduate preparation of teachers as the major source of modern professional pedagogic preparation strategy determination.

The purpose of the article. Integration of Ukraine into international education sphere, essentiality of study and implementation of human experience in the sphere of professional preparation of teachers defined the problem of our research that consists in study and analysis of experience of professional preparation of teachers in the USA.

The main material of the study. A clear definition of the classic view of the term "professionalism" is the first step towards understanding the value of professionalism for modern education and practice. Ideology of professionalism is based on functionalist models of John Goody, Robert Merton, Talcott Parsons. The problem of social control of expert evaluation can be successfully solved by the concept of professionalism. Experts are needed to provide services to clients who are not well informed to adequately assess them [3]. Professional qualifications must be created in order to motivate employees to acquire preservice education and training and constantly improve skills of workers during their professional life. From the perspective of the concept of qualification and competence J. Leino formed a structure that consists of knowledge and ability to perform a professional task [5, p. 71- 90]. The basic principle of teacher training is continuous improvement of teachers' professional qualifications and competences. Every teacher's professional activity competence is important for general educational process [2, p. 3 - 32]. So we can conclude that competence is a motivating factor responsible for personality achievements.

Scholars came to the conclusion that association of colleagues or experts (professional associations) is an important tool for improving competence of professionals. For example, in the United States National Council for the Accreditation of Teacher Education defines key competences that a future teacher must possess in pre service training; National Board for Professional Teaching Standards develops qualification requirements for a National Teacher Certificate; National Institute of Education conducts research related to increase the level of professional competence of American teachers. M. Eraut [3] emphasizes importance of professional preparation and of higher education arguing that activities currently defined as professions (occupations) use several teaching and training methods and their combinations such as: 
1. The period of pupilage or internship. During this period students spend a significant amount of time studying their «craft» from an expert.

2. Admission to «a professional college» which is not a part of higher education system.

3. Qualification examination which is usually established by a qualification association by type of activity.

4. The period of study at a college, polytechnic or classical university which allows to gain an academic qualification.

5. Collection of evidence of practical competence in the form of logbook or portfolio.

Each of these methods makes significant contribution to a knowledge base of a student and into the process of student's socialization into profession. Understanding the role of professionalism in the work of a teacher is impossible outside of professional sector and without demonstration of real life experience of teachers [6, p. 177-189]. This argument is based on certification and licensing and denies arguments regarding teacher's professionalism not based on social experience which is the very essence of teacher profession.

A. Ismat [4] states that there are four criteria that form traditional view of the notion «profession»: remuneration, social status, autonomous or authoritative power and performance of responsibilities. These characteristics include professional autonomy; well-defined, highly developed, specialized and theoretical knowledge base; control of education, certification and licensing of teachers-beginners; self-governing body with particular respect for professional ethics; an obligation to serve society. According to the scientist's conviction, teaching is not a technical (rational) or skillful task performance since the context of teaching is closer to the texture of upbringing in particular the performance of parenting. The nature of teaching the context in which it exists and the process by which the type of activity traditionally turns into a profession makes it impractical and undesirable to use traditional models of professionalization of teaching. It should be noted that professionalization is the best way to improve working conditions of teachers and schoolteaching itself. At the same time it is obvious that some of the main features associated with professions do not exist in teacher's profession. Teachers should have as high qualifications as possible. They should meet the requirements of teacher profession and be interested in it. Teachers must cultivate the right attitude, be faithful and professionally fit. All these will help them successfully teach nowadays children who in the near future will master our world.

Analysis of the works of famous scholars confirms the need for concentration of teachers around universities as this enables the increase of academic level of teacher education and intensification of interaction between education and research. Reform should be directed to a system of education in which basic education is corresponding formal qualifications that are relatively universal and can easily be completed by further education. The perspective is to coordinate all teacher training programs. At the same time professional preparation of a teacher should also cover other branches of science $[8$, p. 26-30].

Influence of global processes is multidimensional and has meaningful social, economic and political implication. Massed distribution of education and «western» norms of education at all levels is a greater part of globalization process. Globalization becomes the subject of research, especially in the sphere of comparative pedagogy, which applies historiography and social-scientific theories and methods of international education problems decision. In the process and theory of globalization school plays an important role as the basic formal agency of knowledge transmission. Distribution of education as a component of globalization process is considered to be the contribution to the process of world democratization.

New approaches need considerable strategic and procedural reforms of both the system of public higher education and the state general system that will be resulted in modernization of long-term strategies and methods that do not answer modern demands. These reforms will need collaboration of leaders of higher education, governors and public school administrators in overcoming of political barriers and support of new idea of professional preparation of teachers. Thus teachers must understand significance of their position in the society and their responsibilities to the community. Professional activity of teachers contributes to the development of the school system in accordance with the principles of democracy. Education should be continuous. Increase of further education of teachers is expected: every five years a teacher is obliged to take professional development courses.

Conclusions and prospects for further research of the direction. So we may conclude that in order to increase educational potential of the country much attention should be paid to improving the system of professional preparation of teachers as only due to highly educated 
teachers the country would be able to take a decent place in the world and be competitive. The level of school cannot be better than the professional level of teachers who work there so improvement of education system of each country depends directly upon the quality of professional preparation of teachers. Education should be coordinated with each stage of the country's development. Educational infrastructures in the school system are worthless if there are no trained, competent teachers to manage them. This has been shown to be a significant difference between academically competent teachers and professionally qualified teachers.

Professionalization is the best way to improve working conditions of teachers and their professional activity. Measures taken to improve the skills of teachers in many states of the USA are primarily driven by modification strategies, which are influenced by strengthening of the role of the state in the education system.

Most of the analyzed studies emphasize the need for academic education as a supplement to professional preparation and in-service training for teachers. Higher Professional Education and advanced training are the most promising ways to improve any professional activity.

Among the promising areas of further research tendencies of professional preparation of teachers in Ukraine, reform of professional preparation of teachers in Ukraine deserve special attention.

\section{СПИСОК ДЖЕРЕЛ}

1. Шандрук C. Тенденції професійної підготовки вчителів у США : [монографія] / Світлана Шандрук. - Кіровоград : Імекс ЛТД, 2012. $496 \mathrm{c}$.

2. Day, C. Professionalism, Performativity and Empowerment: Discourses in the Politics, Policies and Purposes of Continuing Practice Development / C. Day, J. Sachs // International Handbook of Continuing Professional Development, 2004. P. 3-32.

3. Eraut, M. Development Professional Knowledge and Competence / M. Eraut. - London: Falmer Press, 1994. 262 p.

4. Ismat, A. Professionalizing Teaching: Is There a Role for Professional Development Schools? [Електронний pecypc] / A. Ismat. - ERIC Clearinghouse on Teacher Education Washington DC, 1992. - Режим доступу: http://www.ericdigests.org/1992-3/ teaching.htm.

5. Leino, J. Developing and Evaluation of Professional Competence / In Ruohotie, P. (Eds). Professional Growth and Development: Direction, Delivery and Dilemmas. - Canada and Finland, 1996. - P. 71-90.

6. Shacklock, G. Teacher conduct of life / G. Shacklock // Asia-Pacific Journal of teacher education, 1998. - Vol. 26(3). P. 177-189.
7. Shandruk, S. Contemporary Professional Preparation of Teachers in Ukraine / Shandruk, S. // Наукові записки / Ред.кол. В. Ф. Черкасов, В. В. Радул, Н. С. Савченко та ін. - Випуск 150. - Серія: Педагогічні науки. - Кіровоград: РВВ КДПУ ім. В. Винниченка, 2016. С. 43- 47.

8. Shandruk, S. Professional Preparation of Teachers in the USA and in Ukraine: Comparative Analysis / Shandruk, S. // Наукові записки / Ред.кол. В. Ф. Черкасов, В. В. Радул, Н. С. Савченко та ін. Випуск 149. - Серія: Педагогічні науки. Кіровоград: РВВ КДПУ ім. В. Винниченка, 2016. C. 34-39.

9. Shandruk, S. Teacher Education Reform in the USA / Shandruk, S. // Науковий вісник Національного університету біоресурсів і природокористування України. Серія «Педагогіка, психологія, філософія» / Редкол.: С. М. Ніколаєнко (відп.ред) та ін. - К. : Міленіум, 2016. - Вип. 233. C. 300-306.

\section{REFERENCES}

1. Shandruk, S. (2012). Tendentsii profesiyniyi pidgotovky vchyteliv $u$ USA. [Tendencies in professional preparation of teachers in USA]. Kirovograd.

2. Day, C., J. Sachs. (2004). Profesionalizm, performatyvnist' ta rozshyrennya mozhlyvostey: dyskursy v politytsi, politytsi ta tsilyakh podal'shoho rozvytku praktyky. [Professionalism, Performativity and Empowerment: Discourses in the Politics, Policies and Purposes of Continuing Practice Development].

3. Eraut, M. (1994). Rozvytok profesiynykh znan' ta kompetentnosti. [Development Professional Knowledge and Competence]. London.

4. Ismat, A. (1992). Profesionalizatsiya vykladannya: chy isnuye rol' u shkolakh profesiynoho rozvytku? [Professionalizing Teaching: Is There a Role for Professional Development Schools?].

5. Leino, J. (1996). Rozvytok ta otsinka profesiynoyi kompetentnosti. [Development and Evaluation of Professional Competence].

6. Shacklock, G. (1998). Vchytel's'ke vedennya zhyttya. [Teacher conduct of life].

7. Shandruk, S. (2016). Suchasna profesiyna pidhotovka vchyteliv v Ukrayini [Contemporary Professional Preparation of Teachers in Ukraine]. Kirovohrad.

8. Shandruk, S. (2016). Profesiyna pidhotovka vykladachiv u SSHA ta v Ukrayini: porivnyal'nyy analiz. [Professional Preparation of Teachers in the USA and in Ukraine: Comparative Analysis]. Kirovohrad.

9. Shandruk, S. (2016). Reforma osvity vchyteliv u SSHA. [Teacher Education Reform in the USA]. Kyiv.

ВІДОМОСТІ ПРО АВТОРА

ШАНДРУК Світлана Іванівна - доктор педагогічних наук, професор, завідувач кафедри лінгводидактики та іноземних мов Центральноукраїнського державного педаго- 


\begin{tabular}{|c|c|c|}
\hline $\begin{array}{l}\text { гічного універсг } \\
\text { Винниченка. }\end{array}$ & Володи & Department of Linguodidactics and Foreign \\
\hline $\begin{array}{l}\text { Наукові інтереси: } \\
\text { компаративна педагогіка. }\end{array}$ & професійна & $\begin{array}{l}\text { inian State Pedagogical University. } \\
\text { Circle of scientific interests: professional }\end{array}$ \\
\hline
\end{tabular}

INFORMATION ABOUT THE AUTHOR

SHANDRUK Svitlana Ivanivna - Doctor of Pedagogical Sciences, Professor, Head of the education, comparative pedagogy.

Стаття надійшла до редакиії 23.01.2020 p.

УДК : $378637.011 .3-051: 78.7 .071 .2$

DOI: 10.36550/2415-7988-2020-1-186-73-77

\begin{abstract}
АШИХМІНА Наталія Віталіїна -
кандидат педагогічних наук, старший викладач кафедри диригентсько-хорової підготовки Д3 «Південноукраїнський національний педагогічний університет імені К. Д. Ушинського» ORCID: https://orcid.org/0000-0001-8843-5217 e-mail: ashihmina_n-81@ukr.net
\end{abstract}

\title{
СУТНІСТЬ МІЖОСОБИСТІСНОЇ ТВОРЧОЇ ВЗАЄМОДІЇ НА ЗАНЯТТЯХ 3 ДИРИГЕНТСЬКО-ХОРОВОЇ ПІДГОТОВКИ МАЙБУТНІХ УЧИТЕЛІВ МУЗИЧНОГО МИСТЕЦТВА
}

\begin{abstract}
Постановка та обгрунтування актуальності проблеми. Стрімкі соціальні перетворення, що відбуваються в сучасному суспільстві, формують нові принципи життєдіяльності людей. Вони зумовлені процесами соціальної інтеграції та посиленням динамічності змін, що викликають зниження можливостей сталого розвитку i домінування ситуації невизначеності. Це вимагає від освітніх інститутів, зокрема вищої школи, підготовки компетентних фахівців, здатних ефективно взаємодіяти 3 оточуючим світом. Актуальність заявленої проблеми підтверджують європейські та українські документи про освіту, в яких уміння взаємодіяти віднесені до переліку основних компетенцій сучасного фахівця.
\end{abstract}

Освіта, орієнтована на принципи міжособистісної взаємодії, проявляється не стільки в передачі культурного досвіду, скільки в його трансформації у внутрішню, рефлексивну свідомість, що зумовлює перехід особистості до нового стану. 3 онтологічних позицій освіта - це процес взаємодії смислів у світі культури, в результаті якого відбуваються зміни у світі та в людині.

Міжособистісна взаємодія в контексті мистецької освіти, зокрема на творчій основі, здатна збагатити процес музичного навчання здобувачів вищої художньо-педагогічної освіти особливим смисловим ставленням, наповнити перетворювальним змістом.

Педагогіка мистецтва $є$ художньо- педагогічною взаємодією як співтворчість різних «Я», як зустріч суб'єктів із різними стилями мислення, духовними горизонтами, які суттєво збільшують горизонт особистісного бачення і розкривають глибину осягнення смислів. Для художньопедагогічної діяльності важлива установка на проникнення, на процеси напруженої внутрішньої роботи, на душевні зусилля, спрямовані на самопізнання i пізнання Іншого, впізнавання себе в Іншому та Іншого в собі.

Художньо-педагогічна взаємодія, зокрема на заняттях 3 диригентсько-хорової підготовки в педагогічному університеті, сприяє розширенню можливостей майбутнього вчителя музичного мистецтва щодо набуття необхідного сенсу в художньоосвітній галузі через спів-буття 3 творами музичного мистецтва, викладачем, концертмейстером. Емоційна форма сенсу це продукт перетворювального динамічного розвитку особистості майбутнього фахівця. Спілкування на заняттях 3 мистецтвом хорового диригування допомагає становленню у здобувачів вищої освіти образу «ідеального Я», яке формується на основі «реального Я», але містить «Я» Інших, значущих для студентів.

Нажаль, сьогодні в існуючій практиці навчально-професійних відносин між майбутнім учителем музичного мистецтва, викладачем 3 диригентсько-хорової підготовки i концертмейстером процес їх міжособистісної творчої взаємодії 